\title{
Mapping Model of City Branding Formulation in Indonesia
}

\author{
Ratnaningsih Damayanti \\ Department of Government Science, Unibraw \\ Brawijaya University \\ Malang, Indonesia \\ ratnaningsih86@gmail.com \\ Restu Karlina Rahayu \\ Department of Government Science, Unibraw \\ Brawijaya University \\ Malang, Indonesia
}

\author{
Irma Fitriana Ulfah \\ Department of Government Science, Unibraw \\ Brawijaya University \\ Malang, Indonesia
}

\begin{abstract}
Recently, many areas in Indonesia are making city branding. For example in 2015 Malang City launched "Beautiful Malang". In the same year, Special Region of Yogyakarta (DIY) launched "Jogja Istimewa" replaced the previous city branding "Jogja Never Ending Asia", while Surabaya City was far earlier that around 2007 launched "Sparkling Surabaya". The tagline is used as a city branding that aims to highlight the uniqueness of the region. The purpose of making city branding is aslo an effort to raise tourist arrivals to the area. The previous study of these topics focusess on the impact of city branding on tourists visit. What scholars forget about is the city branding that attracts tourists to a certain region born from a well formulation process. This paper will try to map the model of city branding in three areas. By using qualitatives methods, this paper tries to identify how the begining of branding discourse in these three areas raised, the actors that are involved, and the process of formulating city branding. This research shows three kinds of city branding formulation from three areas. First, in Malang City, city branding is made unintentionally because it was a strategy to promote tourism. Second, in Yogyakarta, local government collaborate with many actors in the process of making city branding. Third, in Surabaya city, the idea of city branding formulation born from private sector. In the end, city branding formulation is a form of local government innovation to improve the economic growth of the region.
\end{abstract}

Keywords-formulation; city branding; government innovation

\section{INTRODUCTION}

Regional autonomy has implications on the granting of authority to local governments in managing their own resources such as the authority to make much money to meet the needs of local government expenditure. In making their own money, local governments are given a container through PAD (Pendapatan Asli Daerah or Locallygenerated Revenue). PAD consists of local taxes and levies. They will be proud of their area if the PAD is higher than other regions. PAD which continues to rise from year to year is one indicator that must be achieved by local government.

One of the ways to increase PAD is by increasing tax rates and levies. However, this policy will only be done within a few years according to the economic development of the community. Another way that can be realized is to add a new tax type such as a tax for boarding house that is performed by Malang Government. This boarding house tax became one of the objects of hotel tax.

Nowadays, the local government not only relies on taxes by raising it or adding the types. Another attempt carried out by the local government is by optimizing the aspects that can provide additional revenue for the region. Tourism is one of the sectors that is most developed by the local government. It is believed that they will get a lot of multiplier effects from the sector. For an instance, when a peak season came, investment will rise and the economy level will also increase. Investments in the field of tourism are considered to support hotel business, restaurants, transportation, and entertainment venues. Communities around the tourism area will also get real benefits from the development with the opening of new jobs related to tourism such as tour guides, entertainers, and others.

One of the strategies used by local government in developing tourism is to make city branding. City branding is the effort made by local government to promote the region through the provision of brand or identity including the creation of the image of the area. As identity refers to an identification that distinguishes between one and another, then, the identity of this region provides an identification that is different with other regions. City branding is made with regard to the potential of the superior area which is different from other regions so as to attract tourists to visit the area. The labeling of the area should also be different with other regions.

Until 2017, there were many areas that launched a local brand. In 2015, Malang has launched "Beautiful Malang" as 
the city's brand replacing "Malang Asoy" and "Welcoming Malang". On the other hand, in 2013, Batu has launched the "Shining Batu" replacing the "Kota Wisata Batu" or "KWB". Further down the previous year, Banyuwangi also launched a city branding that is"The Sun Rise of Java" in 2010 replacing the previous brand that already existed. In 2017, Pontianak has officially announced the logo "Pontianak Kota Katulistiwa" to complete the promotion of one of the cities. Malang, in this year, also ready to launch "Kabupaten Malang: The Heart of East Java". Meanwhile, other provinces such as DKI Jakarta already has its city branding called "Enjoy Jakarta" and Pekalongan with "Kota Batik".

The city branding in each region is intended to highlight the potential of the area. For example, Pekalongan wants to highlight its area that has a lot of batik industry; Surakarta is famous for "The Spirit of Java" which wants to highlight its Javanese culture;Special Region of Yogyakarta as a special region in Java has "Jogja Istimewa" to specialize the cultural and regional government system. In correlation to that, the desire of Malang Government to accentuate its beauty is not less behind.

The formulation of city branding in these areas turned out to have various issues. The term "Sparkling Surabaya" and the effort to make city branding comes from the collection of the employers in this crocodile-symbol city. The commitment to work together is not well-maintained in between the proposer and the government so that the implementation of this city branding is only a tagline on the website or on public facilities ${ }^{1}$.

The head of the region has an important role in formulating city branding. A visionary leader who has strong desire to promote the region is able to formulate city branding in accordance with his vision. Banyuwangi is one of the examples where the Mayor has a dominant role in formulating city branding ${ }^{2}$. Then,the ideas of the Mayor are offered to stakeholders in the region.

Batu City has serious effort in formulating their city branding because the government deliberately make a study for this policy. The local government hired a consultant to conduct a city branding study that would replace "Kota Wisata Batu" which has been widely known to Batu people. In the end, it is voted to be "Shinning Batu" which one of its goals is to attract foreign tourists ${ }^{3}$.

The most prominent implementation of city branding is on the deployment of city branding logo. City branding logo is different with the logo of the local government. City

\footnotetext{
${ }^{1}$ Irma Fitriana Ulfah dkk, 2016, Laporan Penelitian Analisis City Branding Kabupaten Kota di Jawa Timur, FISIP UB, Unpublished.

${ }^{2}$ Ratnaningsih Damayanti, dkk, 2017, Banyuwangi City Branding: Regional Promotion and Improvement of Annual Nett Regional Revenue (PAD) Evaluation on Implementation Impact of City Branding in Banyuwangi Year 2013-2015, Proceeding International Conference on Social, Humanities, and Government Science 2017: 161-167.

${ }^{3}$ Op.cit
}

branding logo has simpler and more artistic design than local government logo which seemed to be stiff and complex. In the making of this logo, it requires a longer and different process. To find the right logo, sometimes the local government has to hire a consultant or open a competition as carried out by Special Region of Yogyakarta and Pontianak.

Evaluation in several regions in Indonesia shows that city branding is able to provide a positive impact. City branding is able to raise the tourists in $\mathrm{Batu}^{4}$, Banyuwangi ${ }^{5}$, and Surabaya ${ }^{6}$. City branding also often associated with PAD. The number of tourists visiting a region could give an impact on the increase of PAD from other sectors such as hotel, industry, restaurants, and entertainment. In the period of 2010-2015, Banyuwangi has already succeeded with "Sun Rise of Java" which raises their own revenue rapidly? In Batu City, city branding is able to raise the investment climate. Investment in hotels, restaurants, and souvenir centers is known to experience a rise from year to year ${ }^{8}$.

City branding could be implemented in various ways. The government of Surakarta or better known as Solo made a lot of cultural events which could attract tourists. These cultural events are managed by the Department of Culture and Tourism and are written into the event calendar'. Special Region of Yogyakarta has a city branding that is "Jogja Istimewa". The implementation of this city branding is by distributing the brand in various places that replace the "Jogja Never Ending Asia".

Tulungagung also reported formulating their city branding.Tulungagung is a small industry-based district. In this region, there is also another potential that can attract tourists. Past historical relics, especially in archaeological fields are found in several locations. A prehistoric relic of human history is also found here. With the theme of history, Tulungagung designed a city branding with the tagline of "The Beginning of Life" 10 .

\footnotetext{
${ }^{4}$ Lita Ayu Wandari, dkk, Pengaruh City Branding "Shining Batu” terhadap City Image dan Keputusan Berkunjung Wisatawan ke Kota Batu tahun 2014, Jurnal Administrasi Bisnis (JAB) Vol.16 NO. 1 November 2014: 1-6, ${ }^{5}$ Ratnaningsih Damayanti, dkk, 2017, Banyuwangi City Branding: Regional Promotion and Improvement of Annual Nett Regional Revenue (PAD) Evaluation on Implementation Impact of City Branding in Banyuwangi Year 2013-2015, Proceeding International Conference on Social, Humanities, and Government Science 2017: 161-167 ${ }^{6}$ Ramadhan, dkk, Pengaruh City Branding terhadap Minat Berkunjung Serta Dampaknya pada Keputusan Berkunjung (Survei pada Wisatawan Kota Surabaya), Jurnal Administrasi Bisnis (JAB) Vol. 28 NO. 1 November 2015

7 Op.cit.

${ }^{8}$ Irma Fitriana Ulfah dkk, 2016, Laporan Penelitian Analisis City Branding Kabupaten Kota di Jawa Timur, FISIP UB, tidak diterbitkan

${ }^{9}$ Ina Primasari dkk, City Branding Solo Sebagai Kota Wisata Budaya Jawa (Studi Deskriptif Kualitatif Tentang City Branding Solo Sebagai Kota Wisata Budaya Jawa Oleh Dinas Kebudayaan Dan Pariwisata Kota Solo), Jurnal Komunikasi Massa,

http://www.jurnalkommas.com/docs/JURNAL\%20INNA.pdf

${ }^{10}$ http://www.timesnusantara.com/baca/147016/bupati-berkomitmenkembangkan-aneka-wisata-di-tulungagung/acced on Mei $15^{\text {th }} 2017$ 09:45:10 WIB
} 
Special Region of Yogyakarta and Malang in 2015 have launched a new city branding that replaces the old city branding. Surabaya, on the other hand, is a city that has long a long-time city branding as "Sparkling Surabaya" since 10 years ago. These three areas have a different model of city branding formulation. This paper aims to map the formulation of city branding in three regions, that are Malang City, Surabaya City and Special Region of Yogyakarta.

\section{RESEARCH METHODS}

The research method used in this paper is qualitative with descriptive analysis. The data collection techniques used are interview and documentation. Interviews were conducted for the employees of local government, the Department of Culture and Tourism, and Regional Development Planning Board (BAPPEDA). The interview was conducted to know the data related to the background of city branding arrangement, the formulation process, and the implementation of city branding.

The type of data used is primary and secondary data. Primary data were obtained through interviews with informants who have been determined while the secondary data were the documents from the local government of Malang, Surabaya, and Special Region of Yogyakarta.

After the information is collected, then it is analyzed qualitatively to organize the information into one pattern and category and one basic description unit so that the theme can be found and the hypothesis can be formulated. Qualitative data analysis is a method of data analysis conducted by using techniques of logic to conclude the review of the data that are difficult to measure with numbers.

\section{RESULTS AND DISCUSSION}

1. City Branding Formulation in Special Region of Yogyakarta

Special Region of Yogyakarta (DIY) is one of the provinces in Indonesia. Unlike other provinces that claimed to be one territory with Indonesia, DIY has a different history of governance. After the independence of Indonesia, Yogyakarta through Sultan HB IX chose to join the Republic of Indonesia in 1945, although in fact, they were able to establish their own state. This is because the region of Ngayogyakarta was an empire lead by a Sultan. Indonesia's president at that time, Soekarno, granted this area as a special area that is equal to provincial level. Thus, it can be seen that DIY has its own special features both in terms of culture and the formation of its government. In its development, DIY consists of 4 districts and 1 municipality.

"Jogja Istimewa" is not the first city branding owned by DIY. Previously, DIY has a city branding called "Jogja
Never Ending Asia". The brand began to take effect around 2000. This first city branding was made by Sultan HB X as the impact of the enactment of regional autonomy law. The tagline was initiated around 1998 and was claimed to be the first in Indonesia. With the enactment of the regional autonomy law, it gave a greater authority to regional governments to boost economic growth. Sultan HB X as the Governor of DIY made "Jogja Never Ending Asia" as the city branding to attract stakeholders to invest, attract tourists, and as a symbol of Jogja ${ }^{11}$. The background of this city branding formulation was the economic crisis which caused the DIY economy to decrease. In making the logo of "Jogja Never Ending Asia", Hermawan Kertajaya who is an expert on marketing was chosen to help.

By looking at this background, the main purpose of the formulation of "Jogja Never Ending Asia" is to improve the regional economy. The making of this tagline does not offend the social-cultural value owned by Jogja. In further developments, the tagline is intended to attract investors and tourists to visit Jogja. Investment, in this case, is able to urge the construction of the hotel, shopping centers, and strategic residentials.

"Jogja Never Ending Asia" is designed only for 5 years. The tagline should have been over in 2005 , therefore, after 2005 , the tagline was almost forgotten in the society. Due to an economic priority (profit), the implementation of this city branding seemed to pay less attention to the cultural values of Jogja and public interests. Traffic jam, environmental degradation, and reconstruction are some of the negative impacts of the too much economic downturn.

In 2013, Sultan HB X began to propose a rebranding. This rebranding was intended to replace the "Jogja Never Ending Asia" into the new brand. The implementation of Act of DIY in 2012 was one of the factors influencing the change of Jogja brand. The values that underlie the exceptionalities of Jogja also need to be highlighted in the new city branding. Sultan HB X as the Governor of DIY commissioned the new brand to the BAPPEDA of DIY. For this exclusive formation of this new brand, Sultan HB X asked BAPPEDA to involve the community in the formulation.

The steps undertaken by BAPPEDA of DIY in carrying out the rebranding tasks were, firstly, conducting preliminary studies with literature studies involving artists. Second, BAPPEDA conducted the selection of stakeholder aspirations by organizing a Focus Group Discussion (FGD) and public test. Third, they created a website that is intended as a forum for the community to participate in the branding preparation. At this stage, BAPPEDA also formed "Team 11 " which was assigned to select the brand suggestion from the community. The team consisted of artists, intellectuals, academics, and branding scientists.

\footnotetext{
${ }^{11}$ BAPPEDA DIY, 2014. Laporan Pelaksanaan Uji Publik “Urun Rembuh Logo Baru Jogja", page 11
} 
The fourth stage was the socialization of Yogyakarta new brand to the public. Fifth, the formation of City Branding Council in charge of assisting, monitoring, and evaluating the implementation of Yogyakarta city branding. The activities in this study were identifying and to inventory the program or activities that have a branding nuance, performing escort, and planning the next action ${ }^{12}$.

The implementation of the preparation of Yogyakarta new city branding took a long time. Aware of the lack of ability in the preparation process, BAPPEDA conducted a study by holding many parties. In 2014, BAPPEDA hired Hermawan Kertajaya, the man who also involved in the preparation of previous Yogyakarta brand. Then, they made a study inviting artists and humanists of Yogyakarta to know the condition, construction, and the ideal image of Yogyakarta in the future. This study generated a recommendation from the tagline "New Life New Harmony". The tagline was the result of Hermawan Kertajaya recommendation.

The next step was to make Urun Rembug Logo Baru Jogja Public Test activities. The event was attended by the DIY Regional Leadership Communication Forum, Regent/Mayor of Yogyakarta, scholars, humanists, artists, professionals, academicians, and Head of SKPD, Regional Government of DIY ${ }^{13}$. Through this public test activity, the tagline of "New Life New Harmony" was socialized to the public. In this activity, the tagline was rejected for several reasons such as the logo that was impressed ugly and does not include elements of the typical Yogyakarta religious values. In the new tagline, there is no smart spirit and the appearance of the logo seems to be less attractive. Lastly, it was the logo of the "New Life New Harmony" that was considered to be the result of various matching; it is doubtful that it can be a successful logo.

The rejection of the offered logo and tagline became viral in various social media. This condition, then, was utilized by BAPPEDA as a proposal and reference. To facilitate the input from the community, BAPPEDA formed "Team 11" which its task was to provide input to the formation of Yogyakarta new brand and to select proposals from the community. The proposals from the community were accommodated through the website www.urunrembugiogja.com. In order to increase interest, BAPEEDA prepared a prize money of IDR 200,000,000 for the selected logo and tagline while for the participating community, they got a certificate sent to their home. From many public inputs on the website, Sultan HB X chose "Jogja Istimewa" with the red tagline.

The socialization of this Yogyakarta new brand was done in several ways. First, the images or visual forms were disseminated through various means such as stickers, billboards, videos, banners, and so forth. Subsequently, the

\footnotetext{
${ }^{12}$ Rissa Nurmala Firdaus. 2016. Peran BAPPEDA DIY dalam Mendesain Identitas Baru. Prodi Ilmu Pemerintahan FISIP UB. Unpublished.

${ }^{13}$ BAPPEDA DIY, Op.Cit., page 5
}

installation was done in public places by holding various parties such as state-owned enterprises and private companies. The state companies which were invited to socialize this new city brand were PT. KAI (Indonesian Railways Company), Post Office, BNI Bank, BRI Bank, Mandiri Bank, and BTN Bank. The private parties also did a socialization by putting a new brand of Yogyakarta around their building. On the other hand, the private parties who contributed were several hotels including Jambuluwuk Hotel, Jayakarta Hotel, Quality Hotel, Phoenix Hotel, and Horizon Hotel. People who work in the field of buying and selling merchandise of Yogyakarta souvenirs also rollicking to use this new logo.

The second effort to socialize this new brand was to create Pisowanan Agung. Pisowanan Agung is an activity that only exists in Yogyakarta. It is an activity that is apart from formal government activities.Pisowanan Agung is an activity in which the people facing the Sultan to give abulu bhakti (devotion or service) in the form of rebranding that will become Yogyakarta heritage to face the challenges of the times. This event was held at Pagelaran Keraton Yogyakarta.

In these activities, the people handing "Jogja Istimewa" to Sultan HB X. The event was filled with sabdatama of Sri Sultan HB X regarding the new brand and the giving of brand books to all regent/mayor in DIY. The award to 7 people which have the best logo idea and 24 people for the best tagline was also implemented in Pisowanan Agung. They get an award with a total prize of IDR 200 million and a charter ${ }^{14}$. Pisowanan Agung was attended by BAPPEDA of DIY, the recipient of the awards, all related provincial SKPD, as well as private parties. The private parties attending this big event were BCA, Sahid Rich Hotel, Mirota Batik, Ambarukmo Plaza, Matahari, Ramayana, XL, Natasha, Tribun Jogja, and more.

Thirdly, BAPPEDA socialized the new brand of Yogyakarta through activities carried out in the districts/cities, among them, was through Cultural Revitalization of "Gotong Royong" Activity. In the event, the socialization of "Jogja Istimewa" could be pinned and its implementation in the district is divided into 8 forces. The participants of this activity were a district, sub-district, the village head, village apparatus, BPD, LPMD, TP PKK in DIY ${ }^{15}$.

Fourth, the new brand was disseminated through the mass media. It was through talk shows, public service advertisements such as in TV and radio, community talks in TV programs, radio interactivity, and publications through newspapers. In addition, some social media were also used for socialization such as Social Media Buzzing

\footnotetext{
${ }^{14}$ Nur. 2015. Jogja Gumregah akan Diramaikan dengan Tumpengan. Jogjawara, XLIII (03): 23

15 Pemerintah Daerah Istimewa Yogyakarta. 2015. Laporan Akhir Realisasi Penggunaan Dana Keistimewaan Daerah Istimewa Yogyakarta Tahun Anggaran 2015.
} 
\#JogjaIstimewa and the photo contest via social media with \#JogjaIstimewa.

In its implementation, in 2015, the local government of DIY has made mobile phone application that is called Jogja Istimewa. This government-made app contained all the information services on Yogyakarta. All information ranging from culture, tourism, education, business, health, transportation, public service, even information about entertainment are presented. In 2016, several programs associated with the privilege of DIY including the arrangement of Malioboro were laid out as well as the arrangement of traditional markets, urban transport and fortress transport structuring, garden procurement, museum development, cultural heritage preservation, and the construction and development of Cultural Park in district/city of DIY region ${ }^{16}$.

With the above explanation, it can be concluded that the formulation process of city branding in DIY is a collaboration of various actors. Although the initiation came from the Governor (the government), the implementation involves government elements (BAPPEDA) and community (artists, academics, and the general public). In its socialization, it involves private sector such as banking, craft industry, hotels, shopping centers, and so forth. By involving various parties in the process of formulation and socialization, this makes "Jogja Istimewa" become easily internalized within the local government and society. The government then took action in following up the new brands with continuous programs and without any instruction, the people are busy making crafts with Jogja Istimewa logo as a new souvenir of Jogja.

The cohesiveness of various actors is inseparable from the underlying political context. The passage of Act of DIY Privileges in 2012 made Yogyakarta people who have been fighting for the Act framework make the rebranding moment of Jogja Never Ending Asia as a venue for joint of meanings and distinctive identity implementation.

In Indonesia, Yogyakarta is the first region who launched city branding in 2000, this makes the Governor of DIY be really innovating in the field of governance to improve the regional economy. City branding is intended to put forward the region's identity as a follow-up to the enactment of Law Number 13 of 2012 on the DIY Privileges. This suggests that the joint issue (in this case is DIY privilege) is able to mobilize all elements to participate in creating city branding. The generated city branding was internalized in various circles through their daily activities. In this case, city branding is composed of the strong desire of all circles and not because of following trends.

\section{City Branding Formulation in Surabaya City}

\footnotetext{
${ }^{16}$ BAPPEDA DIY. 2016
}

The city of Surabaya is one of the major cities in Indonesia, even one of the largest cities after Jakarta. The capital of East Java Province is located in this city. Surabaya also has a big port for many ships. Therefore, this city, since pre-colonial era, has been a busy trading center. From east to north, the city is bordered by Madura Strait. Here lies the bridge that connects Madura Island with Java in which this became the hope to connect the economy between Surabaya and Madura. In the west, this city is bordered by Gresik regency and bordered by Sidoarjo regency in the south.

The people of Surabaya work as employees and traders. In the center of the city, we will found many office and trading buildings. Become the capital of East Java, it makes many office centers located in this city. The number of business activities that are in this city makes the supporting industry also growing. The hotel industry, trading, and transportation are very developed in Surabaya, a city with crocodile symbol. The largest mall in East Java also located in this city. Furthermore, international airport and travel business that has a path to almost all regions in Java Island also developed in Surabaya.

Due to its close proximity to the sea, Surabaya is a region with lowland type. Most of its territory is at an altitude of 3-6 meters above sea level ${ }^{17}$. This lowland type makes the property industry grow rapidly such as the property industry that is intended for households or residential, office, and entertainment.

Of the many economic activities in the city, Surabaya has high economic growth. In 2010, the economic growth of Surabaya can exceed East Java and even national economic growth. The economic growth of Surabaya, at that time, was $7,09 \%$ while the provincial and national economic growth was $6,68 \%$ and $6,20 \%{ }^{18}$. In the next six years, from 2011 to 2016, the economic growth in Surabaya is also always higher than the East Java province and national economic growth. The average of Surabaya economic growth from 2011 to 2016 is $6,8 \%$. The average economic growth of East Java in the same period is $5,98 \%$, while the average national economic growth is only $5,5 \%$.

The industry development in Surabaya is also influenced by the advertisement industry which aggressively promoted its various products. From 2011 to 2014, the realization of advertisement (billboard) tax tends to rise. Its contribution to the Locally-generated Revenue (PAD) during this period is $5,61 \%^{19}$. In addition to the billboard tax, during 2009 to 2011, street lighting tax, restaurant tax, and hotel tax has ranked as the third major PAD in Surabaya. In 2012 to 2014, since the Law of Tax-Transfer imposed in Surabaya, the property tax and the tax of land and building acquisition became the new sources of

\footnotetext{
${ }^{17}$ http://bappeda.jatimprov.go.id/bappeda/wp-content/uploads/potensi-kabkota-2013/kota-surabaya-2013.pdfacced on Mei 15 ${ }^{\text {th }} 2017$ 10:04:20 WIB ${ }^{18}$ RPJMD Kota Surabaya tahun 2010- 2015

${ }^{19}$ DPKK Kota Surabaya tahun 2015
} 
revenue. The entertainment tax during that time also tends to rise and the realization of the taxes continues to be above $100 \%$ S.

Considering that Surabaya is a business center, a lot of people from out of town or overseas come to do business in this city. Besides city government, hotel, restaurant, and entertainment are affected by the arrival of business people who will invest or do other business activities. The longer the entrepreneurs stay in this city, the more profitable it is for the hotel, restaurant, and entertainment.

Today, Surabaya is known to have a tagline "Sparkling Surabaya". This tagline has been made long ago, which is about 2006 or 2007 . This idea was first raised by the hotel owners by carrying the sparkling lights of Surabaya at night (after they finished doing business during the day). To reinforce this idea, they offer the tagline "Sparkling Surabaya" to the government of Surabaya.

The idea offered by these entrepreneurs was greeted positively by the local government with the establishment of Surabaya Tourism Promotion Board (STPB). Its content is to give an integration concept between private parties and government to support the city branding of Surabaya. This organization is chaired by Surabaya Plaza owner Yuzak Anshory and consists of entrepreneurs in Surabaya while the government is represented by BAPPEKO and Surabaya Tourism Office ${ }^{20}$. The result of this organizational performance leaves a visible mark on taxis, city buses, government activities, portal or gate in villages, and public facilities in Surabaya.

Thus, the formulation process of city branding in Surabaya was initiated by private parties consisting of a group of entrepreneurs in Surabaya. After that, they seek support to the government and legitimize its implementation. The legalization was only limited to the manufacture of the organization and not in the stage of the strong legal umbrella. Also, the organization did not involve other elements as it only consisted of businessmen and representatives of the government.

After the branding is realized, the tax on hotel, restaurant, and entertainment during 2009 to 2014 always increase from year to year. Starting from 2011, the realization of these three taxes was always above $100 \%$. This proves that "Sparkling Surabaya" has a positive impact on the revenue growth of these three sectors and for the PAD of Surabaya.

Unfortunately, the implementation of "Sparkling Surabaya"was not accompanied by a strong legal framework so that, in 2016, when the legal umbrella and STPB committee were traced, there are no footsteps. Weak legal protection makes the commitment of the government to internalize "Surabaya Sparkling" only a tagline. Surabaya City Government has its own way to boost the regional

\footnotetext{
${ }^{20}$ Irma Fitriana Ulfah dkk, 2016, Laporan Penelitian Analisis City
} Branding Kabupaten Kota di Jawa Timur, FISIP UB, Unpublished. economy by creating separate policies like the Investment Climate Improvement Program and Investment Realization.

\section{City Branding Formulation in Malang City}

Malang is a fast-growing city in East Java Province. Historically, Malang is a city that has been developed before the Dutch Colonial Government came to this area. Malang was once a kingdom centered in Dinoyo area (an area located in Lowokwaru subdistrict). Its famous king is Gajayana which then enshrined into a street name in Dinoyo area.

In the mid-18th century, the Dutch colonial government entered the city to take control of this area. The Dutch colonial government just set up its government in the early 19th century by building a central government around Brantas River. In the 19th century, they began to design city planning complete with the residential areas construction for Dutch officials and families. Until now, those historical buildings remain in the area of Jalan Ijen ${ }^{21}$. This area also seems to be more neat and nice compared to other areas which back then were intended for natives.

The arrival of the Dutch in Malang had an immediate impact on the development of the city such as the facilities that were originally intended for Dutch people like trains, school buildings, military bases, hotels, and so forth. In a further development, Malang became the city of education. Many major universities are located in this city, such as Universitas Brawijaya, State University of Malang, and UIN Maulana Malik Ibrahim.

The construction of train station and airport in Malang also has a positive impact on the economic development of Malang. Malang Kota Baru train station is the nearest station to go to Batu which is known as a tourist town. Malang is also used by travelers to transit to other cities, for example, tourists both domestic and foreign who want to go to Mount Bromo usually transit in this city. In 2014, according to BPS Malang, the number of foreign tourists who come to Malang were 60,195 people while the domestic tourists amounted to $1,146,080$ people; they will stay in hotels around Malang. The number of hotels in Malang, in 2014, was 84. The hotels are divided into fivestar hotels, budget hotels, and other accommodations such as a boarding house or guest house.

Besides hospitality industry which receives the impact, Malang also gets benefits from restaurants. By 2015, there were 921 restaurants, this data increased up to $47 \%$ from the previous year ${ }^{22}$. It shows that Malang is increasingly considered to be an area of investment in the food industry.

${ }^{21}$ http://malangkota.go.id/sekilas-malang/sejarah-malang/acced on $15 \mathrm{Mei}$ 2017 11:05:30 WIB

${ }^{22}$ LAKIP Dinas Pendapatan Kota Malang tahun 2015 
Not just a city that is used as a transit point, Malang wants to become a tourist destination. The city branding of "Welcoming Malang" was designed in 2006. However, this tagline is not able to strongly promote Malang in the field of tourism.

In 2015, the Government of Malang launched "Beautiful Malang". It was organized as a strategy of Malang City to promote its tourism. This strategy was prepared by the Department of Culture and Tourism and the logo and tagline were internally compiled by them. When this strategy is submitted to the Mayor, the marketing strategy is actually passed into city branding. This city branding was finally launched on Malang Flower Carnival which then replaced Welcoming Malang.

To promote and legalize Beautiful Malang, the Mayor of Malang published a circular letter that leaves a message to attach a sticker or logo throughout all organizations, governments, and companies such as schools, universities, hotels, restaurants, cafes, and so forth. In the circular letter, it is mentioned that Beautiful Malang is a city branding ${ }^{23}$.

When it is seen from the formulating process, Beautiful Malang was formulated not as a city branding but as a tourism marketing strategy. It can be concluded that this city branding was drafted by the government unintentionally. This gives an effect to the increased burden of the Department of Culture and Tourism which, initially, was only responsible for tourism marketing.

The process of logo or design formulation of this city branding was not open for public, thus, it was criticized by the association of graphics designer. The implementation of Malang city branding also unknown for government agencies outside the Department of Culture and Tourism. People are clueless towards this formulating process. By that, the city branding was difficult to be internalized within the government and among the public.

\section{CONCLUSION}

From the explanation above, the three models of city branding can be formulated. First, city branding is formulated in the top-downsystem by the government. People in this concern just follow the advice of the government. The impact of this model is that the city branding will be less internalized in the community. The internalization process requires a relatively long time, the government needs to create programs related to city branding so that it can be internalized in the government scope.

Second, the process of city branding comes from the private sector. They offer the city branding to the municipality and as a result, they need a strong legal umbrella to legalize it. If the government does not create a

${ }^{23}$ Interview with Agung, Dinas Kebudayaan dan Pariwisata on Agustus $28^{\text {th }}$ 2017 clear legal framework, the programs related to the implementation of city branding will be difficult to implement. Another negative impact is that the city branding is only limited to logo and tagline and it will be easily forgotten by society.

Lastly, the city branding is formulated jointly by the government and society. The open formulation process has a positive impact for the internalization of the city branding. Various dialogue and the serious study also needed in the formulation process. The involvement of government, public, and private parties in the implementation of city branding also makes the dissemination of city branding becomes more massive and effective.

From the three models above, it can be known the seriousness of the government in formulating the city branding. Therefore, the formulation of different models will produce a different impact of city branding.

\section{REFERENCES}

Journals/Proceedings/Paper/Thesis:

[1] Firdaus, Rissa Nurmala. 2016. Peran BAPPEDA DIY dalam Mendesain Identitas Baru. Penelitian Tidak Diterbitkan. Malang: Prodi Ilmu Pemerintahan FISIP UB.

[2] Primasari, Ina, dk. City Branding Solo Sebagai Kota Wisata Budaya Jawa (Studi Deskriptif Kualitatif Tentang City Branding Solo Sebagai Kota Wisata Budaya Jawa Oleh Dinas Kebudayaan Dan Pariwisata Kota Solo), Jurnal Komunikasi Massa, http://www.jurnalkommas.com/docs/JURNAL\%20INNA.pdf

[3] Ramadhan, dkk. Pengaruh City Branding terhadap Minat Berkunjung Serta Dampaknya pada Keputusan Berkunjung (Survei pada Wisatawan Kota Surabaya), Jurnal Administrasi Bisnis (JAB). Vol. 28 NO. 1 November 2015

[4] Damayanti,Ratnaningsih dkk. 2017.Banyuwangi City Branding: Regional Promotion and Improvement of Annual Nett Regional Revenue (PAD) Evaluation on Implementation Impact of City Branding in Banyuwangi Year 2013-2015, Proceeding International Conference on Social, Humanities, and Government Science 2017: 161-167

[5] Ulfah, Irma Fitriana dkk. 2016. Laporan Penelitian Analisis City Branding Kabupaten Kota di Jawa Timur. Penelitian Tidak Diterbitkan. Malang: FISIP UB.

[6] Wandari, Lita Ayu, dkk. Pengaruh City Branding "Shining Batu" terhadap City Image dan Keputusan Berkunjung Wisatawan ke Kota Batu tahun 2014, Jurnal Administrasi Bisnis (JAB). Vol.16 No. 1 November 2014: 1-6

Website:

[7] http://www.timesnusantara.com/baca/147016/bupati-berkomitmenkembangkan-aneka-wisata-di-tulungagung/acced on Mei $15^{\text {th }} 2017$ 09:45:10 WIB

[8] http://bappeda.jatimprov.go.id/bappeda/wp-content/uploads/potensikab-kota-2013/kota-surabaya-2013.pdfacced on Mei $15^{\text {th } 2017}$ 10:04:20 WIB

[9] http://malangkota.go.id/sekilas-malang/sejarah-malang/acced on Mei $15^{\text {th }} 11: 05: 30 \mathrm{WIB}$

Government Report:

[10] DPKK Kota Surabaya tahun 2015

[11] LAKIP Dinas Pendapatan Kota Malang tahun 2015 
[12] BAPPEDA DIY, 2014. Laporan Pelaksanaan Uji Publik "Urun Rembuh Logo Baru Jogja", halaman 11

[13] Pemerintah Daerah Istimewa Yogyakarta. 2015. Laporan Akhir Realisasi Penggunaan Dana Keistimewaan Daerah Istimewa Yogyakarta Tahun Anggaran 2015.

[14] RPJMD Kota Surabaya tahun 2010- 2015

Magazine:

[15] Nur. 2015. Jogja Gumregah akan Diramaikan dengan Tumpengan. Jogjawara, XLIII (03): 23

Interview:

[16] Agung, Dinas Kebudayaan dan Pariwisata pada 28 Agustus 2017 